Central Washington University

ScholarWorks@CWU

2-26-2013

\title{
2012 Haida Gwaii Quake: Insight Into Cascadia's Subduction Extent
}

Walter Szeliga

Follow this and additional works at: https://digitalcommons.cwu.edu/geological_sciences

Part of the Geophysics and Seismology Commons, and the Tectonics and Structure Commons 
Eos, Vol. 94, No. 9, 26 February 2013

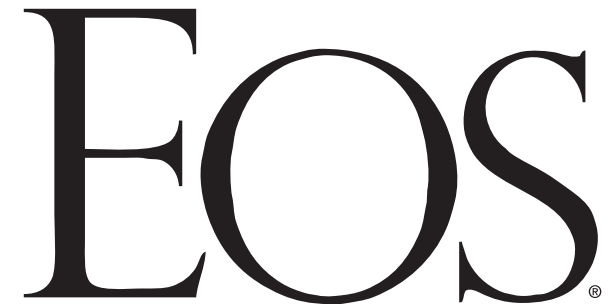

EOS, TRANSACTIONS, AMERICAN GEOPHYSICAL UNION
VOLUME 94 NUMBER 9

26 FEBRUARY 2013

\section{Haida Gwaii Quake: Insight Into Cascadia's Subduction Extent}

\section{PAGES $85-86$}

The limits of Cascadia were first defined to contain nearly the entire margin of the Pacific Northwest, from Cape Mendocino through the Alaska Panhandle [Schuchert, 1910; Schuchert and Barrell, 1914]. Since that time, the boundary of Cascadia has shrunk to become essentially synonymous with the region where the Juan de Fuca plate subducts beneath the North American plate.

As a consequence, seismic hazard assessments in the Pacific Northwest have conventionally focused on the potential for large megathrust earthquakes along the interface of the Juan de Fuca and North American plates.

The 28 October 2012 M7.8 Haida Gwaii earthquake (Figure 1), however, suggests that the northern terminus of subduction along the Cascadia margin may need to be redefined; such a redefinition has ramifications for seismic hazard analysis along the entire west coast of the United States and Canada.

\section{Tectonic Setting of Northern Cascadia}

Off the coast of northern British Columbia, subduction of the Juan de Fuca plate beneath the North American plate gives way to a transform fault between the Pacific plate and North American plate: the Queen Charlotte fault system (QCF). This fault system extends northward from the Explorer plate, a microplate chipped off the Juan de Fuca plate, to Baranof Island, Alaska, where it transitions into the Fairweather fault and related structures (see Figure 1). Over the past century, these fault systems have hosted several large earthquakes, including the 1899 M8 Yakutat, the 1949 M8.1 Queen Charlotte, the 1958 M7.7 Lituya Bay, and the 1972 M7.6 Sitka. Recent geodetic velocity estimates along the QCF suggest that relative plate motion is primarily strike slip, with a smaller component of convergence. This finding is supported by the 22 August 1949 M8.1 Queen Charlotte Island earthquake (Figure 1), which displayed a right-lateral first motion and presumably occurred along the main trace of the QCF just offshore of the northern island of Haida Gwaii.

South of the 1949 epicenter the trace of the QCF forms a restraining bend where the relative motion between the North American and Pacific plates is more transpressional- meaning that the plates are converging with each other as well as translating past each other-with approximately 19 millimeters per year of convergence expected. The Haida Gwaii earthquake provides evidence for how this convergence is accommodated, with a hypocenter east of the mapped Queen Charlotte fault at a depth of about 20 kilometers and a dominantly reverse focal mechanism, a signature of convergence (Figure 1).

\section{How Does the QCF Accommodate Motion?}

The oblique nature of plate motion along the QCF has led to two end-member models to describe how transpressional strain is accommodated: through distributed compression along crustal faults in both the Pacific and North American plates [Rohr and Tryon, 2010] and through subduction of the Pacific

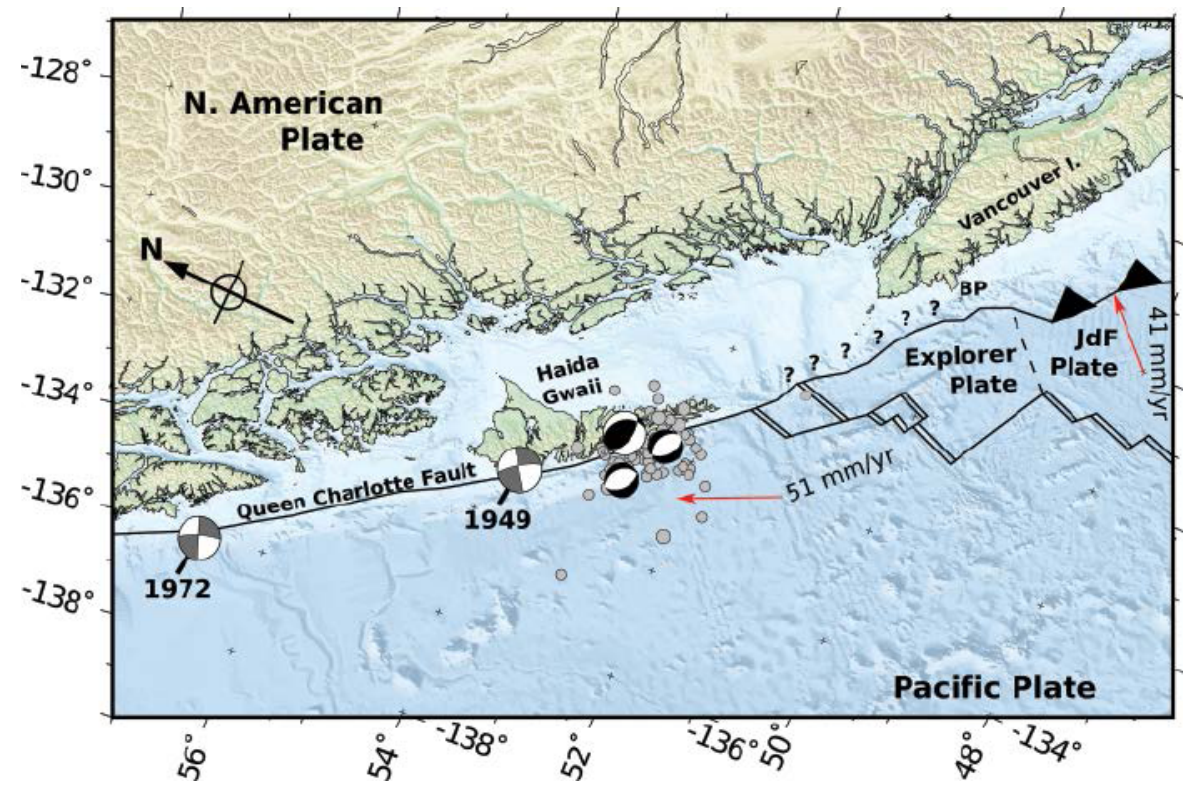

Fig. 1. Map of the Queen Charlotte fault system showing the general tectonic layout. Earthquake focal mechanisms (beach balls) are drawn with compressive quadrants filled; unlabeled focal mechanisms are from the 2012 sequence, and those with dates show large historical earthquakes. Aftershocks from the 2012 sequence are marked by gray circles; aftershocks from the 1949 and 1972 earthquake are not shown. Earthquake epicenters are from the International Seismological Centre catalog. Red arrows show relative plate motion velocities according to the Mid-Ocean Ridge Velocity (MORVEL) model's reference frame for North America [DeMets et al., 2010]. The Brooks Peninsula (BP) on Vancouver Island and the Nootka fault (dashed line) mark the current northern limit of the Cascadia subduction zone. The boundary between the North America plate and Explorer plate is indicated with question marks and does not appear to be actively subducting. The locations of the spreading centers are from Wilson [2002] and are schematic. JdF is Juan de Fuca. 
Eos, Vol. 94, No. 9, 26 February 2013

plate beneath the North American plate [Yorath and Hyndman, 1983; Hyndman and Hamilton, 1993]. Other interpretations intermediate to these two end-member models exist, and additional references may be found in these papers.

In the distributed crustal fault model the QCF acts as the plate boundary and serves to accommodate strike-slip motion between the Pacific and North American plates, while convergence is accommodated along smaller crustal thrusts in both plates. This model is supported by the occurrence of $M 8$ strike-slip earthquakes, the occurrence of $M 6$ thrust earthquakes but a historical lack of thrust earthquakes with a magnitude larger than $M 6$, and the absence of a seismically detectable slab north of the Brooks Peninsula on Vancouver Island (Figure 1).

In contrast, the subduction model suggests that the Queen Charlotte fault is not the plate boundary but is instead a strike-slip fault within the fore arc of the North American plate. In this scenario, convergence is accommodated along the plate boundary interface between a subducting Pacific plate and an overriding North American plate. The subduction model is supported by a downward flexural bulge in the Pacific plate, parallel low and high free-air gravity anomalies centered along the QCF, and a seismically imaged, 10-kilometer-thick, slablike structure beneath Haida Gwaii interpreted to be the eastward dipping partially subducted Pacific plate [Bustin et al., 2007].

Oblique subduction such as this occurs in other, more tectonically mature, regions, such as Sumatra, the western Aleutian Islands, and the Philippines. In these regions, strain is partitioned between large strike-slip structures in the overriding plate and thrust faulting along the subduction interface. In all of these regions, focal mechanisms in any single earthquake typically show either pure strike-slip or pure thrust mechanisms and only rarely a blend.

\section{Which Model Is Correct? New Insight From the 2012 Haida Gwaii Earthquake}

The 28 October $2012 M 7.8$ main shock is the first instrumentally recorded major thrust earthquake along this segment of the QCF. The aftershocks of the 2012 earthquake span approximately 140 kilometers in the alongstrike direction, and finite fault inversions from both the California Institute of Technology and the U.S. Geological Survey
(USGS) suggest a large (150 kilometer $\times 40$ kilometer) along-strike and downdip region of fault rupture. These fault dimensions indicate an unusually large downdip faulting dimension, which is more consistent with a shallowly dipping fault and would be unusual for a vertically dipping fault.

Additionally, the locations, focal mechanisms, and strikes of the two largest aftershocks (M6.5 and M6.3; Figure 1) are suggestive of outer-rise normal faulting earthquakes, shown to follow other much larger subduction earthquakes, such as the 1960 Chile, 2004 Sumatra, and 2011 Tohoku earthquakes [e.g., Lay et al., 2011, and references therein]. In general, outer-rise normal faulting earthquakes are indicative of tensional plate-bending and slab-pull stresses, and their occurrence is related to temporal changes in plate coupling following subduction. All of these observations provide evidence for the oblique subduction model.

Similar to the 1949 Queen Charlotte earthquake, the October 2012 main shock was widely felt throughout the coastal Pacific Northwest, with reports from as far away as Juneau, Alaska (650 kilometers), and Seattle, Wash. (900 kilometers). In addition, a little more than an hour after the main shock, Deep-ocean Assessment and Reporting of Tsunami (DART) buoys in the northern Pacific Ocean recorded a small open ocean tsunami, and an alert was issued for the Hawaiian Islands. While the subsequent tsunami wave heights proved to be smaller than anticipated (1.2 meters at Wailoa Harbor, Hawaii, and 0.76 meters at Kahului, Maui), the fact that this section of the plate margin was able to generate a distal tsunami at all suggests that subduction along the QCF presents an underappreciated hazard to the Pacific Basin.

\section{Hazard Reassessments and the Need for Further Research}

The occurrence of the Haida Gwaii earthquake suggests that subduction in the Pacific Northwest resumes north of the Explorer plate, with the Pacific plate descending beneath North America. Further research will be needed to verify the extent of subduction along the QCF and fault systems farther north. Pending the outcome of this research, a reanalysis of what is defined as the extent of subduction along the Cascadia margin may be in order. With this new definition the scientific community may also need to reassess the implications for seismic hazard not only along the margin itself but also to the rest of the Pacific Basin.

\section{Acknowledgments}

"Did You Feel It?" data are courtesy of USGS. Focal mechanisms and magnitude for the 2012 earthquake were contributed by USGS and the National Earthquake Information Center in Golden, Colo. Earthquake locations were contributed by the International Seismological Centre. Tim Melbourne and Craig Scrivner deserve special thanks for fruitful discussions, as do Anne Egger, Chris Mattinson, and Lisa Ely for keen proofreading.

\section{References}

Bustin, A. M. M., R. D. Hyndman, H. Kao, and J. F. Cassidy (2007), Evidence for underthrusting beneath the Queen Charlotte Margin, British Columbia, from teleseismic receiver function analysis, Geophys. J. Int., 171, 1198-1211, doi:10.1111/j.1365-246X.2007.03583.x.

DeMets, C., R. G. Gordon, and D. Argus (2010), Geologically current plate motions, Geophys. J. Int., 181, 1-80, doi:10.1111/j.1365-246X.2009.04491.X.

Hyndman, R. D., and T. S. Hamilton (1993), Queen Charlotte area and Cenozoic tectonics and volcanism and their association with relative plate motions along the northeastern Pacific margin, J. Geophys. Res., 98(B8), 14,257-14,277.

Lay, T., C. J. Ammon, H. Kanamori, M. J. Kim, and L. Xue (2011), Outer trench-slope faulting and the $2011 \mathrm{Mw} 9.0$ off the Pacific coast of Tohoku earthquake, Earth Planets Space, 63, 713-718.

Rohr, K. M. M., and A. J. Tryon (2010), PacificNorth America plate boundary reorganization in response to a change in relative plate motion: Offshore Canada, Geochem. Geophys. Geosyst., 11, Q06007, doi:10.1029/2009GC003019.

Schuchert, C. (1910), Paleogeography of North

America, Bull. Geol. Soc. Am., 20, 427-606.

Schuchert, C., and J. Barrell (1914), A revised geologic time-table for North America, Am. J. Sci., 38(223), 1-27.

Wilson, D. S. (2002), The Juan de Fuca plate and slab: Isochron structure and Cenozoic plate motions, in The Cascadia Subduction Zone and Related Subduction Systems, edited by S. Kirby, K. Wang, and S. Dunlop, U.S. Geol. Surv. Open File Rep., 02-328, 9-12.

Yorath, C. J., and R. D. Hyndman (1983), Subsidence and thermal history of Queen Charlotte basin, Can. J. Earth Sci., 20, 135-159.

—Walter SzEliga, Geological Sciences Department, Central Washington University, Ellensburg; E-mail: walter@geology.cwu.edu 